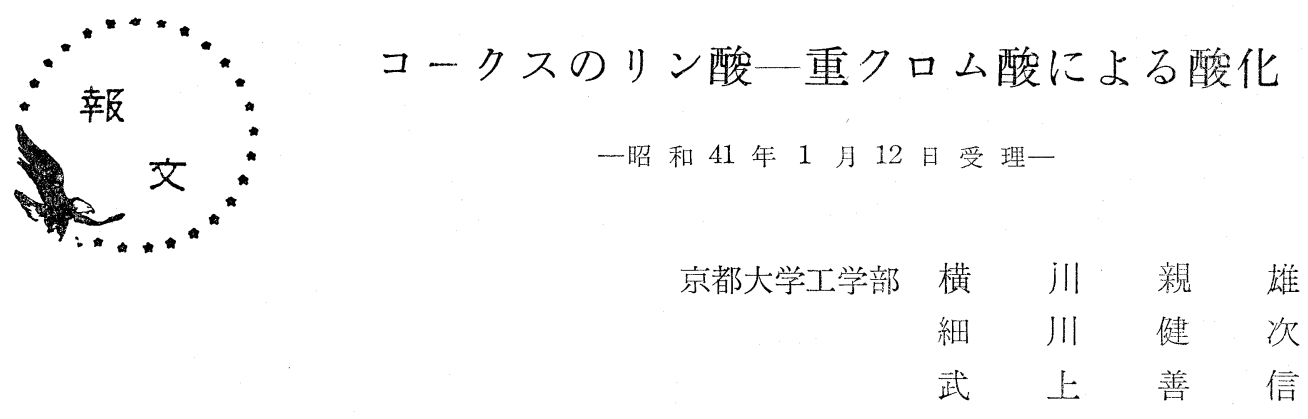

\section{I. 緒 論}

リン酸一重ク口ム酸による酸化 (以下湿式酸化と呼 ぶ）はカーボン類の炭化, 黒鉛化の過程にお预る構造 変化を研究する場合の有力な手段の一つとて広く知

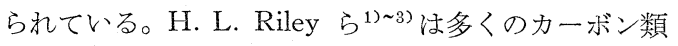
をこの酸化剂を用いて酸化し, 酸化速度が黒鉛化の進 行とともに増大することを認めた。赤松ら ${ }^{4)}$, 杉山ら ${ }^{5)}$ および須賀6) も同様の実験を行なつたが，これら諸研 究の一致した結論によるとカーボン類の湿式酸化に対 する抵抗はカーボン類の結晶（グラファイト型の平板 を想定する）の層間架橋によるもので, 架橋密度が小 さくなるにつれて結晶子が酸化液中に分散しやすくな るために全体として酸化速度が大になると理解されて いる。本田ら は各種石炭化度の石炭について湿式酸 化性と石炭の構造との関係を論じたが，この際にあつ ても高石炭化度炭ではカーボン類の場合と同様の解瀵 が成立することを認めている。

石炭のコークス化過程における諸性質 (X線回折 像 $^{879)}$, 反磁性 ${ }^{10)}$, 比重 ${ }^{11)}$, 内部表面積 ${ }^{12)}$ な゙゙)の変化は 粘結性あるいはコークス化性の問題に関連して多くの 研究がある。湿式酸化性の変化住関するものとしては 川名 ${ }^{13)}$ の研究があるが，この場合には $1,000 \sim 2,000^{\circ} \mathrm{C}$ の温度範冉についてのみ実験が行なわれており, 1,000 ${ }^{\circ} \mathrm{C}$ 以下の実験がない。

本研究は各種石炭化度炭について, その炭化過程に おける湿式酸化性の変化を追跡し, その特徴をコーク ス化性との関連において考察しようとするものであ る。

\section{II · 実験}

\section{1. 試料石炭}

試料石炭は中郷褐炭を除いていずれも製鉄用コーク ス製造に用いられる原料炭であつて, その分析值を一 括して Table 1 に示した。
Table 1 Analysis of coals used (daf. \%)

$\begin{array}{lll}\quad \text { Coal } & \mathrm{C} \% & \mathrm{H} \% \\ \text { Nakago } & 72.0 & 5.70 \\ \text { Ōnoura } & 81.5 & 5.87 \\ \text { Cessnack } & 82.2 & 6.33 \\ \text { Syakanoo } & 82.4 & 5.87 \\ \text { Futago } & 82.4 & 6.21 \\ \text { Ioujima } & 82.6 & 6.06 \\ \text { Miike } & 83.3 & 6.10 \\ \text { Yūbari } & 83.7 & 6.38 \\ \text { Wharton } & 87.0 & 5.55 \\ \text { Yatake } & 89.5 & 5.03 \\ \text { Page } & 90.1 & 4.96 \\ \text { Futago-R } & 78.6 & 5.47\end{array}$

2. コークスの調製

i ) 実験室調製: 石炭の熱分解には Gray-King の 装置 ${ }^{14)}$ を用いた。風乾試料 (80 Tyler mesh 以下) 15 $\mathrm{g}$ を加熱速度 $5^{\circ} \mathrm{C} / \mathrm{min}$. (電位差計式自動温度調節器 による）で所定温度 $(400,500,600,700,800$ および $1,000^{\circ} \mathrm{C}$ ) に達せしめ, その後この温度に $1 \mathrm{hr}$ 保持し た。

ii）缶焼：富士製鉄株式会社広畑製鉄所において稼 動中のコークス炉内で常法に従つて調製した。

iii）酸化試料の調製：コークス塊を粗粒にまで破研 して無作意に各部から少量ずっをとり，鉄製乳鉢中で さらに粉硴して Tyler 穊を用いて 100 200，200 250，250 300 および 300 mesh 以下の 4 部に分割し た。穊別に際しては微粉が付着して混入することを避 けるため, 節下が恐められなくなるまで長時間手動で 笠別を続けた。

3. 酸化装置ならびに操作

酸化装置ならびに実験操作は本田らクのものに準じ 
た。乾燥試料 $50 \pm 3 \mathrm{mg}(100 \sim 200$ Tyler mesh，粒度 の影響の項参照）を精科し，酸化剤* $10 \mathrm{~m} l$ を加えて 酸化した。加熱浴には水またはトルエンを用い，それ ぞれ 150min または 90min 反応を継続した。反応中 $5 \mathrm{~min}$ ごとにビューレットの読みを記録し，その度に 反応容器を振湯した。

\section{4. 酸化性の表示}

所定時間酸化を継続したのち得られたガス量を標準 状態に換算し，生成したガスがすべて $\mathrm{CO}_{2}$ であると 仮定してガスになつた炭素の量を求めた。この炭素量 の試料コークスに含まれていた全炭素量（コークスの 元素分析值の表示は省略する）に対する百分率を求め て酸化性とした。

一般に湿式酸化は見掛上零次反応として進行する。 しかし酸化性が著しく大であつたり逆に小であるもの にあっては，Fig.1 亿模型的に示したように零次反応 から離反する傾向がみられる。しかしその離反の程度 は著しいものではなく，一定時間 (150 または 90min) ののちのガス量を基準として酸化性を比較することを 妨げるものではない。また試料量を 50〜100 mg の間 に変動させを場合にも，同様の表示法を用いて全く一

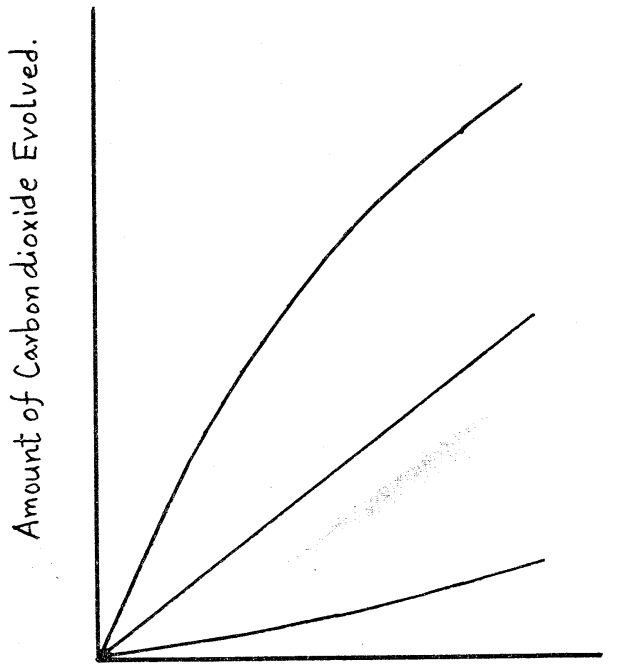

Oxidation Time

Fig. 1 Typical oxidation processes

* $\mathrm{K}_{2} \mathrm{Cr}_{2} \mathrm{O}_{7} 20 \mathrm{~g}$ を比重 1.70 のリン酸 $100 \mathrm{~m} l$ に 溶解し, 防湿装置をつけて保存してある。

** 試料粒を真球と考光, 2 つの Tyler 篩の網目の 径の平均值を平均粒径として計算した值。
致した結果が得られた。

\section{5. 粒度の影響}

数種の石炭およびユークス試料について，相対酸化 性と試料の幾何学的外部表面積**との関係を Table 2 に示した。

目尾炭，夕張炭，双子缶焼コークスにあつては，相 対酸化性と相対幾何学的外部表面積との間に良好な一

\section{Table 2 Effect of particle size}

\begin{tabular}{|c|c|c|c|c|}
\hline Sample & $\begin{array}{c}\text { Particle } \\
\text { size* }\end{array}$ & $\begin{array}{l}\text { Relative } \\
\text { external } \\
\text { surface } \\
\text { area** }\end{array}$ & $\begin{array}{l}\text { Relative } \\
\text { oxidation } \\
\text { rate*** }\end{array}$ & $\begin{array}{l}\text { Tempera- } \\
\text { ture coeffi- } \\
\text { cient**** }\end{array}$ \\
\hline $\begin{array}{l}\text { Nakago } \\
\text { Coal }\end{array}$ & $\begin{array}{l}\text { I } \\
\text { II } \\
\text { III } \\
\text { IV }\end{array}$ & $\begin{array}{l}1.0 \\
1.6 \\
2.6 \\
-\end{array}$ & $\begin{array}{l}1.0 \\
1.1 \\
1.2 \\
1.5\end{array}$ & $\begin{array}{c}1.4 \\
- \\
- \\
-\end{array}$ \\
\hline $\begin{array}{l}\text { Syakanoo } \\
\text { Coal }\end{array}$ & $\begin{array}{l}\text { I } \\
\text { II } \\
\text { III } \\
\text { IV }\end{array}$ & $\begin{array}{l}1.0 \\
1.6 \\
2.6 \\
-\end{array}$ & $\begin{array}{l}1.0 \\
1.6 \\
2.2 \\
5.0\end{array}$ & $\begin{array}{l}2.1 \\
2.1 \\
-\overline{2.5}\end{array}$ \\
\hline $\begin{array}{l}\text { Yübari } \\
\text { Coal }\end{array}$ & $\begin{array}{l}\text { I } \\
\text { II } \\
\text { III } \\
\text { IV }\end{array}$ & $\begin{array}{l}1.0 \\
1.6 \\
2.6 \\
-\end{array}$ & $\begin{array}{l}1.0 \\
1.7 \\
2.0 \\
3.6\end{array}$ & $\begin{array}{l}2.7 \\
2.3 \\
2.3 \\
2.3\end{array}$ \\
\hline $\begin{array}{l}\text { Yatake } \\
\text { Coal }\end{array}$ & $\begin{array}{l}\text { I } \\
\text { II } \\
\text { III } \\
\text { IV }\end{array}$ & $\begin{array}{l}1.0 \\
1.6 \\
2.6 \\
-\end{array}$ & $\begin{array}{l}1.0 \\
1.0 \\
1.1 \\
3.4\end{array}$ & $\frac{2.5}{2.5}$ \\
\hline $\begin{array}{l}\text { Page } \\
\text { Coal }\end{array}$ & $\begin{array}{l}\text { I } \\
\text { II } \\
\text { III } \\
\text { IV }\end{array}$ & $\begin{array}{l}1.0 \\
1.6 \\
2.6 \\
-\end{array}$ & $\begin{array}{l}1.0 \\
1.2 \\
1.2 \\
5.3\end{array}$ & $\begin{array}{l}2.2 \\
2.0 \\
2.1 \\
2.5\end{array}$ \\
\hline $\begin{array}{l}\text { Ōnoura } \\
\text { Coke } \\
\left(1,200^{\circ} \mathrm{C}\right)\end{array}$ & $\begin{array}{l}\text { I } \\
\text { II } \\
\text { III } \\
\text { IV }\end{array}$ & $\begin{array}{l}1.0 \\
1.6 \\
2.6 \\
-\end{array}$ & $\begin{array}{l}1.0 \\
1.2 \\
1.6 \\
5.4\end{array}$ & - \\
\hline $\begin{array}{l}\text { Futago } \\
\text { Coke } \\
\left(1,200^{\circ} \mathrm{C}\right)\end{array}$ & $\begin{array}{l}\text { I } \\
\text { II } \\
\text { III }\end{array}$ & $\begin{array}{l}1.0 \\
1.6 \\
2.6\end{array}$ & $\begin{array}{l}1.0 \\
1.7 \\
1.9\end{array}$ & - \\
\hline $\begin{array}{l}\text { Page Coke } \\
\left(1,200^{\circ} \mathrm{C}\right)\end{array}$ & $\begin{array}{l}\text { I } \\
\text { II } \\
\text { III } \\
\text { IV }\end{array}$ & $\begin{array}{l}1.0 \\
1.6 \\
2.6 \\
-\end{array}$ & $\begin{array}{l}1.0 \\
1.4 \\
1.5 \\
3.6\end{array}$ & $\begin{array}{l}2.1 \\
2.1 \\
2.1 \\
2.0\end{array}$ \\
\hline $\begin{array}{l}\text { Page-Ōnoura } \\
\text { Coke } \\
\left(1,200^{\circ} \mathrm{C}\right)\end{array}$ & $\underset{\text { III }}{\text { II }}$ & $\begin{array}{l}1.0 \\
1.6 \\
2.6 \\
-\end{array}$ & $\begin{array}{l}1.0 \\
1.4 \\
1.6 \\
3.4\end{array}$ & $\begin{array}{l}- \\
\text { - }\end{array}$ \\
\hline $\begin{array}{c}\text { Page-Futago } \\
\text { Coke } \\
\left(1,200^{\circ} \mathrm{C}\right)\end{array}$ & $\begin{array}{l}\text { I } \\
\text { II } \\
\text { II }\end{array}$ & $\begin{array}{r}1.0 \\
1.6 \\
2.6 \\
-\end{array}$ & $\begin{array}{l}1.0 \\
1.5 \\
1.8 \\
4.8\end{array}$ & - \\
\hline
\end{tabular}

* I $100 \sim 200$ Tyler Mesh

II $\quad 200 \sim 250$

III $250 \sim 300$

IV 300 unper.

** Calculated from the mean diameter of particles.

*** Ratio of the amounts of gas evolved after $150 \mathrm{~min}$. oxidation at $100^{\circ} \mathrm{C}$.

**** Ratio of the amounts of gas evolved after 90 min. oxidation at $110^{\circ} \mathrm{C}$ and $100^{\circ} \mathrm{C}$. 
致がみられる。これに対して中郷炭およびページ石炭 では酸化性は 100 300mesh の粒度範囲内で外部表面 積にほとんど無関係に一定であり, ページ缶焼コーク スにあっては 200 300 mesh の範囲内で一定となる。 しかし，いずれの試料についても 300 mesh 以下に粉 砕したものでは酸化性は著しく大きい。一方ヨウ素吸 着法によつて求めた内部表面積*と酸化性との間には 全く相関々係が認められなかつた。をた酸化性の温度 依存性（温度係数）は粒度に無関係であつた。

湿式酸化は固一液不均一系反応であるから, 酸化性 は試料と酸化剂との接触可能面積ならびに酸化剂の拡 散速度に関係する。上述の一連の結果加らも, 酸化性 を支配する物理的要因は複雑であつて個々の試料の性 格によつて異なることがうかがわれるが，異種試料間 の湿式酸化性を比較するには，同一粒度の試料につい て得られた数値を用い，上述のような事情を考虑に入 れて考察する以外涪当な手段がないように思われ る。以上のような観点から, 以下の実験においては最 も調製しやすい 100 200mesh の粒度範囲の試料を用 いることとした。

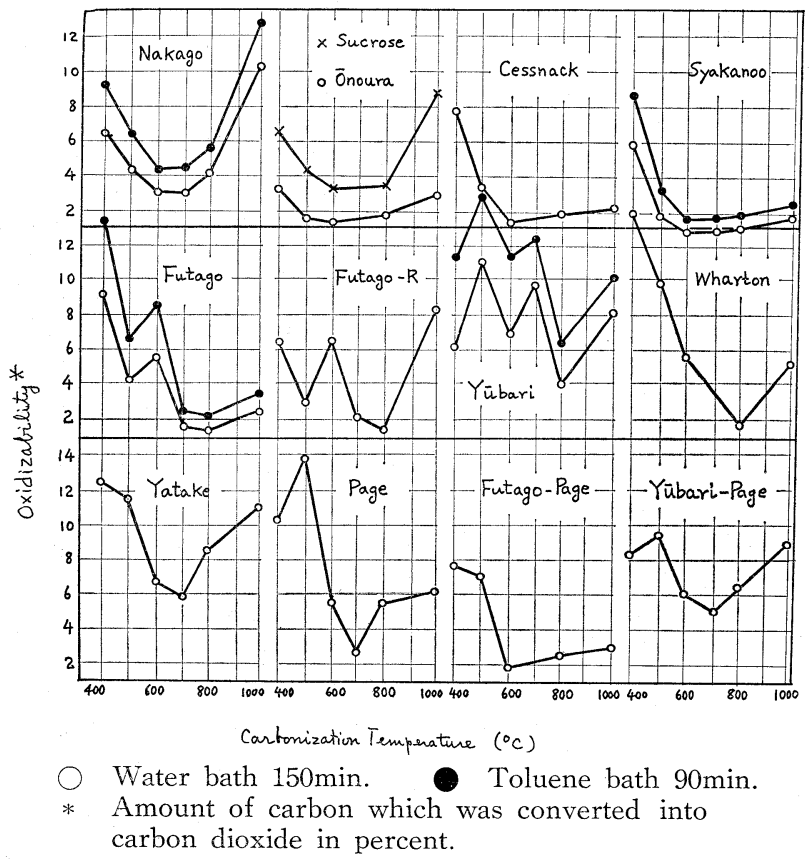

Fig. 3 Variation of oxidizability by carbonization

* 試料 $3 \mathrm{~g}$ を $\mathrm{N} / 10$ ヨウ素ーエタノール溶液に浸積し, 吸着 平衡に達したときの吸着ヨウ素量を求め, 単分子吸着と して求めた值(表示は省略)。

** 双子炭をピリジン抽出した残渣炭。抽出量 $22 \%$ 。

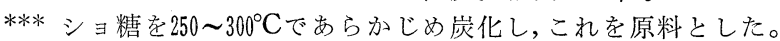

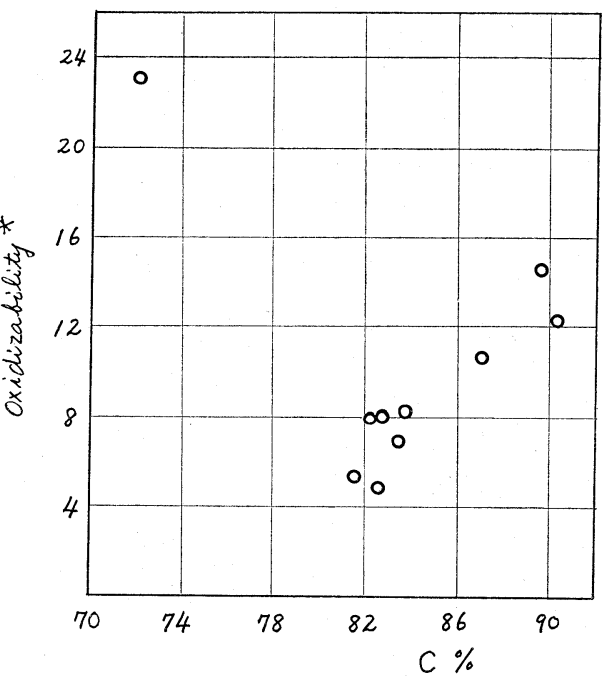

* Amount of Carbon which was converted into carbon dioxide in percent. water bath, 150min.

\section{Fig. 2 Variation of oxidizability} of coal by rank

\section{III. 実験結果および考察}

1. 石炭化度と湿式酸化性

試料石炭 (100 200 mesh) を水蒸気浴の温 度で酸化した場合の湿式酸化性を石炭化度 (daf％) に対して点綴すると Fig. 2 のよう になる。この図はさきに本田らでが示したも のと異るところはないが，本実験に供した試 料炭の性格を示すために掲げた。C $82 \%$ 附近 に極小がみられるが，石炭化過程における石 炭の構造ならびに化学反応性の変化に関する 知見に従つて判断すると，この点を境にして 酸化性を支配する因子が異るものと考えられ る。

2. コークス化過程における

湿式酸化性の変化

中郷, 大八浦, Cessnack, 目尾, 双子, 夕張, Wharton, 矢岳, Page, 双子-R**およびショ 糖炭***を $400 \sim 1,000^{\circ} \mathrm{C}$ で熱分解して得たコ 一クスの湿式酸化性の変化状況を Fig. 3 に 示した。

中郷炭はいわゆる化学反応性が大きいので 酸化性も大であるが， $400^{\circ} \mathrm{C}$ までの熱分解に よつて酸化性は著しく低下する。 $600^{\circ} \mathrm{C}$ に酸 化性の極小があり, それ以後酸化性は増大寸 
るがその程度は弱粘結炭と比較して強い。この状況は ショ糖炭のそれに類似している。大ノ浦, Cessnack, 目尾の 3 者はきわめて酷似した変化状沉を示す。これ ら弱粘結炭の特徵は酸化性が全体的に小さく, 極小值 以後の酸化性の増大が著しく困難なことである。中郷 炭のように石炭化度が極端に低いものにあつては， $400^{\circ} \mathrm{C}$ 以下の低温に㧍いてその基本構造体自体の分解 が起こり，基本構造体同志を結合していた架橋部分を も含めて新しい基本構造体が形成され，これが炭化過 程にある程度整理されるために $1,000^{\circ} \mathrm{C}$ 附近までに比 較的速かな酸化性の増大がみられるのに対し, 弱粘結 炭にあってはその基本構造体自体が比較的熱に安定で あつて架橋密度も高くかつ強固であるために酸化性が 小さく，また熱処理による酸化性の向上も弱いものと 考えられる。一般に弱粘結炭と褐炭以下の石炭あるい はショ糖炭とを比較すると, 後者からのカーボンの方 が黒鉛化しにくいが, $1,000^{\circ} \mathrm{C}$ までの変化は上述のよ らであると思われる。

つぎに双子，夕張などの粘着炭についてみると， $500^{\circ} \mathrm{C}$ 以上の炭化温度領域において酸化性に著しい変 動が認められる。すなわち，酸化性を処理温度に対し て点緅すると図示したよらなジグザグな線が得られ る。これらの図形は $100 \sim 200^{\circ} \mathrm{C}$ 間隔で測定した点を 機械的に結びつけたものであるから，酸化性の変化が 実際に図示されたと㧍りであると主張するわけではな いが，いずれの測定值についてもその再現性* はきわ めて良好であるから，酸化性の変化仁乱秃があること は確実に指摘できる。このような特徵はピリジン抽出 残渣炭（双子-R）においてもみられる。

Wharton, 矢岳, Page などの強粘結炭では炭化に よる酸化性の低下が著しく，ぬた極小点以後の酸化性 の増大も著しい。すなわち，全体としてシャープな曲 線を示すが，粘着炭にみられたような不規則な変動は みられない。

つぎに粘着炭欢子および夕張炭にそれぞれ等量の Page 炭を混合して得たコークスについての結果を Fig. 3 亿示す。図より明らかなように，強粘結炭を配 合すると粘着炭に特有の酸化性の不規則な変化はみら

* 石炭より新しくコークスを調製し，同様の測定 を繰り返しても同じ結果を得た。

** 弱粘結炭の基本構造体は熱的に粘着炭のそれよ り不安定であり, 強粘結炭のそれは粘着炭のそ れより安定であろう。しかし，弱粘結炭にあつ ては半成コ一クスが生成する段階で不安定部分 がほとんど整理されてしまつていると考えられ る。
れなくなる。

以上のように, 石炭の熱分解過程における酸化性の

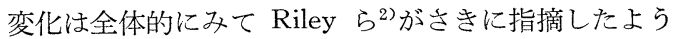
な経過をたどるが，これを詳細にみると石炭の種類に よつてその状況は異なり, 褐炭, 弱粘結炭, 粘着炭お よび強粘結炭といらように石炭を分類するとそれぞれ の群についてその特徵を明確に指摘することができ る。特に粘着炭にみられる特異現象, ならびにこの特 異現象が強粘結炭と混炭することにより消滅すること は，コークス化性の問題と関連して興味がある。

井上ら ${ }^{9)}$ は石炭の熱分解過程をX線回折法で追求 し, 夕張炭コークスでは結晶子の大きさが熱分解過程 に不規則な変化を示すのに対し，米国強粘結炭ではこ のようなことはなく，また両者を混炭することによつ て夕張炭にみられた特異現象が消滅することを認めて いる。この井上らが観察した現象は本実験で認めた現 象と同傾向のものであり，おそらく相互に関連するも のであると考えられる。

一般に $500 \sim 800^{\circ} \mathrm{C}$ の温度領域では, 半成コークス （固化温度まで加熱されたコークス）の基本構造体に 残留している不安定な構造が新しく $\mathrm{C}$ - C あるいは 一O一結合を作りながら解消され，しだいに rigid な 立体構造をとるような変化が起こると理解されてい る。湿式酸化性の変化状況も粘着炭のそれを除いてこ のような解釈で説明し得るものである。弱粘結炭ある いは強粘着炭にあつては, 半成コークスが比較的安定 であるために，この温度領域では全体の性格に急激な 変化をおよぼすような分解を起こさないが**, 粘着炭 にあつては，全体的な変化の方向は同じであつても， この温度領域のある温度において全体の性格に影響を およぼすような激しい変化をする構造部分が含まれて いるものと思われる。

このような半成コークスの不安定構造を具体的に 論じることは至難であるが，粘着炭の特徴である高 水素含有量に着目して説明することができよう。著

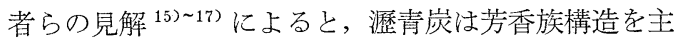
体とする基本構造体とそれらを連絡する脂環族構造部 分とからなり, 半成コークス生成過程（第一次熱分解 過程）の主要な反応は脂環族構造部分の熱分解である と理解される。瀝青炭の基本構造体は上述のように芳 香族構造を主体とするが，その水素含有量から判断し て脂環族構造およびアルキル側鎖を含むもので，この ような基本構造に含まれる比較的安定な水素に富んだ 構造部分は粘着炭にあつて最も多いと考えられる。こ のような構造部分の多くは半成コークスに残留すると 
考えられ，その量もまた粘着炭の場合に最も多いと考 えられる。このような構造部分は $500 \sim 700^{\circ} \mathrm{C}$ で急激 な分解を起こすと考えて差支えなく, 本来半成コーク スの基本構造体としての性格をもつていた部分に本質 的な変化が起こるためにコ一クス全体の性格に著しい 変化が起こると理解できる。強粘結炭と混炭すると, 半成コークスの基本構造が強固な強粘結炭のそれに近 くなり, 不安定部分の密度が減少することと相まつ て, 湿式酸化性あるいは結晶子の大きさの変化倞影響 をおよぼすほどの本質的な変化を起こさなくなるので あらう。

3. コークス強度と湿式酸化性

䍃焼コークス 7 種についてそのドラム試験の結果と 湿式酸化性を対比して Table 3 亿示した。混炭割合は いずれの場合にも日本炭 $60 \%$, Page 炭 $40 \%$ である。

Table 3 Mechanical strength and oxidizability of cokes

\begin{tabular}{lcc}
\multicolumn{1}{c}{ Coke* } & $\begin{array}{c}\text { Drum Index } \\
15 \mathrm{~mm} \%\end{array}$ & Oxidizability ** \\
Ōnoura & 66.6 & 2.54 \\
Futago & 53.2 & 2.03 \\
Ioujima & 49.9 & 2.25 \\
Page & 92.6 & 5.56 \\
Ōnoura-Page & 91.0 & 3.70 \\
Futago-Page & 91.6 & 3.60 \\
Ioujima-Page & 91.6 & 4.05
\end{tabular}

* Prepared in a cun in a commercially operating coke oven.

** Amount of gas evolved from $50 \mathrm{mg}$ of coke after $150 \mathrm{~min}$. oxidation at $100^{\circ} \mathrm{C}$ $(\mathrm{m} l)$.

混炭コークスの酸化性は単味コークスのそれの算術平 均に近い值となり特に顕著な変化はないが，ドラム強 度 $15 \mathrm{~mm}$ 指数は混炭の場合に著しく向上している。 したがつて, コークス強度と湿式酸化性との閒に相関 タ倸を指摘することはできない。しかし, 前項に示し たように粘着炭が半成コークスから高温コークスに変 化する段階に不規則な変化を起こすことは, 粘着炭の コークス化性が悪いことと関連していると思われ，半 成コークスから高温コークスに変化する段階の構造上 の履歷が高温コークスの強度に影響をおよぼすものと 考えられる。

$$
\text { IV. 総括 }
$$

原料炭を主とする石炭11種を選び，単味あるいは混
炭して $400 \sim 1,000^{\circ} \mathrm{C}$ で熱分解した。得られたコーク スをリン酸一重ク口ム酸酸化 (湿式酸化) し, 熱分解過 程における酸化性の変化について考察した。結果の概 要はつぎのようである。

1）一般にコークスの湿式酸化性は $600 \sim 800^{\circ} \mathrm{C}$ で 極小となり, 酸化性一熱分解温度曲線はU宇型となる。

2）酸化性の変化を詳細にみると, 石炭の種類によ つて異なり, 石炭を褐炭, 弱粘結炭, 粘着炭抢よび強 粘結炭といらように分類すると, それぞれの群につい てその特徴を明確に指摘することができる。

3) 粘着炭は特異な挙動を示し, 湿式酸化性一熱分解 温度曲線はジグザグになる。

4）粘着炭の特異な現象は強粘結炭を混炭すること により消滅する。

5) 湿式酸化性とコークス強度（ドラム指数）との 間には直接の関係涊められないが，熱分解過程にお ける湿式酸化性の変化履歴はコークスの強度に影響を もつものと考えられる。

\section{V. 謝辞}

石炭試料の入手, 缶焼コークスの調製ならびにその 強度試験について，富士製鉄株式会社広畑製鉄所化工 部コークス課の諸氏の御厚意を受けた。ここに付記し て謝意を表する次第である。

\section{文献}

1) H. E. Blayden, H. L. Riley, J. Soc. Chem. Ind., 54, 159T (1935)

2) A. E. Balfour, H. E. Blayden, A. H. Carter, H. L. Riley, J.Soc. Chem. Ind., 57, 1 (1938)

3) H. L. Riley, Trans. Farad. Soc., 34, 1011 (1938)

4) H. Akamatsu, H. Takahashi, K. Tamaru, Bull. Chem. Soc. Japan, 24, 27 (1951)

5）杉山幸男，長坂克己，工化，56，81（1953）

6) 須賀操平, 石炭関連物質の炭化に関する研究 (学 位論文) (1959)

7) H. Honda, Y. Hirose, Fuel Lond., 37, 323 (1958)

8) H. E. Blayden, J. Gibson, H. L. Riley, Proc. Conf. Ultra-fine Structure of Coals and Cokes, 76, London (1944)

9) 井上勝也, 安孫子満男, 工化, 59, 37 (1956)

10）本田英昌, 大内公耳, 燃協誌, 33, 579 (1956)

11) R. E. Franklin, Trans. Farad. Soc., 45, 274 (1949)

12) C. G. Cannon, M. Griffith, W. Hirst, Proc. 
Conf. Ultra-fine Structure of Coals and Cokes, 131, London (1944)

13）川名善男, 燃協誌, 33, 237 (1954)

14) G. M. Himus, Fuel Testing, p. 88 (1932)

15）横川, 渡部, 梶山, 武上, 燃協誌, 39, 590 (1960);
Fuel Lond., 41, 209 (1960)

16）武上善信，横川親雄，梶山茂，ibid., 40, 620 (1961)

17）横川親雄, 梶山茂, 武上善信, 燃協誌, 42,176 (1963)

\title{
Oxidation of Cokes by Potassium Bichromate-Phosphoric Acid
}

\author{
by Chikao Yokokawa, Kenji Hosokawa \& Yoshinobu Takegami
}

(Department of Fuel Chem., Faculty of Eng., Kyoto Univ.)

\begin{abstract}
SYNOPSIS : - In order to elucidate the structural change of coke by pyrolysis various kinds of cokes, prepared at different temperatures $\left(400\right.$ to $1,000^{\circ} \mathrm{C}$ ) from coals of various ranks (carbon content, 70 to $90 \%$ ) were oxidized by potassium bichromate in concentrated phosphoric acid at 100 or $110^{\circ} \mathrm{C}$. The rate of carbon dioxide evolution was measured and the oxidizability of cokes was compared. The general mode of change in oxidizability by pyrolysis was the same as that reported by A. B. Balfour et al, i.e. it reaches minimum at a temperature of 700 or $800^{\circ} \mathrm{C}$. The oxidizability of coke becomes higher as the rank of the parent coal increases. In the cases of strongly agglutinating coals (Futago and Yübari) the oxidizability of coke fluctuates widely in the carbonization temperature range of 500 to $800^{\circ} \mathrm{C}$. These fluctuations were diminished when these coals were carbonized after mixing with strongly coking coal. Although there was no direct relationship between oxidizability and mechanical strength (Drum index), it might be concluded that the change of the oxidizability during carbonization process has a fatal effect on the mechanical strength of the final coke.
\end{abstract}

